\author{
Ivana Zajc \\ RTV Slovenija, Ljubljana \\ DOI: 10.4312/SSJLK.57.106-109
}

\title{
Sodobne slovenske dramatičarke: tematsko-formalne novosti in primera sodobnih dramskih besedil za osnovno in srednjo šolo
}

\begin{abstract}
V slovenski literarni zgodovini je dramatičark malo, a močno zaznamujejo dramsko produkcijo po letu 2000 . V prispev$\mathrm{ku}^{1}$ izpostavimo nekatera dela, ki kažejo motivno-tematske novosti in se povezujejo z (ženskim) spolom oziroma ženskimi liki: temo samomora, (nadomestnega) materinstva, bolezni, vloge žensk v skupnosti in pričakovanja družbe do žensk, odraščanja mladostnic, življenje homoseksualnih oseb ter ženske erotike. Razmišljanje sklenemo s predlogoma dramskih besedil avtoric Simone Semenič Pepelka in Varje Hrvatin Kako sem postal lisičje krzno, ki vključujeta pravljične motive ter sta glede na teorije razvoja literarnega branja primerni izhodišči za branje, pogovor in različne tipe uprizarjanja $v$ osnovnošolskem oziroma srednješolskem obdobju.
\end{abstract}

slovenske dramatičarke, dramatika, Simona Semenič, Varja Hrvatin, didaktika književnosti

There are few female dramatists in Slovene literary history, but they have strongly marked drama since 2000. This paper focuses on certain works which are new from a thematic point of view and connected with (female) gender or female characters: the theme of suicide, (surrogate) motherhood, illness, the role of women in the community and society's expectations of women, young women growing up, lesbian themes and female eroticism. Conclusions are drawn using the examples of two plays by female dramatists: Simona Semenič's Pepelka (Cinderella) and Varja Hrvatin's Kako sem postal lisičje krzno (How I Became Fox Fur), both of which include fairy tale motifs and, with regard to theory of development of literary reading, are suitable starting points for reading, conversation and different types of staging in primary or secondary school.

Slovene female dramatists, drama, Simona Semenič, Varja Hrvatin, literary didactics

Čeprav jih je v slovenski literarni zgodovini malo, ${ }^{2}$ pa dramsko produkcijo po letu 2000 zaznamujejo dramatičarke (Pezdirc Bartol 2016: 269-270). V prispevku najprej izpostavimo nekatera njihova dela ${ }^{3}$ z motivno-tematskimi novostmi, ki se povezujejo z (ženskim) spolom oziroma ženskimi liki: temo samomora, (nadomestnega) materinstva, bolezni, vloge žensk v skupnosti in pričakovanja družbe do žensk, odraščanja mladostnic, življenje homoseksualnih oseb ter ženske erotike. $V$ nadaljevanju opišemo nekatere ključne subverzije tradicionalne dramske forme, ki so značilne za dela sodobnih dramatičark. Prispevek sklenemo s predlogoma dramskih besedil avtoric Simone Semenič in Varje Hrvatin, ki sta lahko izhodišči za branje, pogovor in različne tipe uprizarjanja v osnovnošolskem oziroma srednješolskem obdobju. Obe drami si izposojata pravljične motive.

1 Avtorico prispevka pri raziskovanju podpira Univerzitetna ustanova ing. Lenarčič Milana.

2 Mateja Pezdirc Bartol kot prvi dramatičarki omeni Luizo Pesjak, ki je pisala drame o življenju slovenskih literatov, ter Zofko Kveder, med drugim tudi avtorico dramskih besedil, ki prikazujejo družbene vloge žensk, tj. zakonske žene, matere, hčere, intelektualke. Druge avtorice do leta 2000 so še Marija Kmet, Manica Koman, Silva Trdina, Marija Fele, Marija Mijot, Matilda Košutnik, Ilka Vašte, Manica Lobnik, Tanja Drmec, Ljuba Prenner, Mira Mihelič, Alenka Goljevšček in Draga Potočnjak (Pezdirc Bartol 2016: 270).

3 Izbor, ki ga predstavljamo, seveda ne zajame vseh slovenskih dramatičark, ampak se opre na tiste, ki so prejele vidnejše nagrade, imajo širok nabor objav oziroma so njihova dramska besedila uprizarjana. 


\section{Nekatera dela sodobnih dramatičark, povezana z (ženskim) spolom}

Draga Potočnjak je med drugim avtorica del Hrup, ki ga povzročajo živali, je neznosen, Kalea, Za naše mlade dame in Vse lepo in prav. Njena drama Alisa, Alica govori o begunki iz Bosne Alisi, ki se je zatekla k odtujeni Magdi in zaradi globokega občutka nepripadnosti storila

samomor. Žanina Mirčevska je med drugim napisala drame Na deževni strani, Žrelo, Proces in Konec Atlasa. Njeno delo Luknja govori o nadomestnem materinstvu in dojemanju otroka kot kapitalističnega produkta. Tamara Matevc je objavila npr. dela Zaljubljeni v smrt, Sveto čarovniško salo, Petek trinajstega in Aus Anstand - La Siesta. Njeno delo Pepelka v okvir znane pravljice bratov Grimm postavi drugačno zgodbo, in sicer tri polsestre kljub začetni sovražnosti ugotovijo, da je pomembno sodelovati, zato se spoprijateljijo in sklenejo, da bodo izkoristile vsak trenutek svojega življenja.

V okviru Pregleja, odprte platforme za razvoj dramske pisave, ki je delovala v okviru gledališča Glej, so med drugim delovale dramatičarke Zalka Grabnar Kogoj, Simona Hamer, Barbara Skubic, Andreja Zelinka, Saša Rakef in Simona Semenič. Simona Hamer je napisala drame Taubeka, Tiktak, l-z-š-t-e-v-a-n-k-e in Nemi liki. Njeno delo Razglednice ali strah je od znotraj votel, od zunaj pa ga nič ni prikazuje izkušnje slovenskih žensk, ki so si drznile premikati meje. Simona Semenič je med drugim avtorica del 5fantkov.si, tisočdevetstoenainosemdeset, medtem ko skoraj rečem še ali prilika o vladarju in modrosti ter sedem kuharic, štirje soldati in tri sofije. V performansu jaz, žrtev $\mathrm{z}$ ironijo govori o porodu in o spolnih idr. boleznih, $v$ drami to jabolko, zlato pa tematizira žensko erotiko. Nekaj let po zatonu Pregleja je KUD Krik zasnoval dramsko platformo in delavnice dramske pisave Vzkrik, kjer med drugim delujejo dramatičarke Varja Hrvatin, Brina Klampfer, Kaja Blazinšek, Tjaša Mislej in Suzana Tratnik. Drama Najraje bi se udrla v zemljo Varje Hrvatin prikazuje odraščanje treh deklet, ki je hkrati osvobajanje od družbenih prisil. Drama Paloma Brine Klampfer in Kaje Blazinšek skozi zgodovino tovarne toaletnega papirja izriše sliko družbenega razvoja ter med drugim tematizira podrejen položaj ženske. Delo Tjaše Mislej Skladišče preko prikaza težkih delovnih razmer delavk v trgovini spregovori o vlogah, ki jih ženskam pripisuje okolje, in o mentaliteti, ki onemogoča družbene premike. Dramsko delo Suzane Tratnik, ki sicer piše prozna besedila, Tukaj ni homofobije razgrne družbene krivice in nasilje nad homoseksualnimi osebami.

\section{Subverzije dramske forme}

Za sodobno slovensko dramatiko ženskih avtoric niso značilne le nove teme, ampak tudi novi postopki, ki presegajo tradicionalni dramski dispozitiv. Ena od teh subverzij je prevlada avtobiografskosti v dramatiki, ki v središče besedila postavlja avtorico, denimo v trilogiji Žrtve Simone Semenič in v delu Vse se je začelo z golažem iz zajčkov Varje Hrvatin. V tem monološkem tipu dramatike je $v$ ospredju samopripoved v prvi osebi, ki pa odpira vprašanja o tem, ali je izpoved, ki ostaja v okviru dramskega dispozitiva, lahko avtentična. Avtorski glas je pridobil več teže tudi $v$ didaskalijah, kjer je dramatik tradicionalno podajal strnjene napotke za odrsko uprizoritev. Tako vanje med drugim vstopata estetska in pripovedna funkcija. $V$ didaskalijah lahko govori tudi dramski lik, kar je značilno za delo Simone Semenič medtem ko skoraj rečem še ali prilika o vladarju in modrosti. Sodobna dramatika vključuje postopke, ki so značilni za filmske scenarije, pripovedništvo ali liriko, poleg tega vanjo vstopajo dokumentarnost ( $v$ delu Brine Klampfer in Kaje 
Blazinšek Paloma), reklamni oglasi ( $v$ delih Simone Semenič 24ur in drugič) ter spletne igre in klepetalnice (v delu Varje Hrvatin Najraje bi se udrla v zemljo).

\section{Sodobna slovenska dramatika ženskih avtoric $\mathbf{v}$ šoli: dva predloga}

$\checkmark$ nadaljevanju opišemo razvoj literarnega branja, zatem pa predstavimo primera sodobne slovenske dramatike ženskih avtoric, ki imata potencial za branje, oblikovanje predstav, snemanje kratkih filmov ipd. v poznem osnovnošolskem oziroma srednješolskem obdobju. Dramama je skupno, da vključujeta pravljične motive.

Razvoj bralcev književnosti osvetlijo ugotovitve Arthurja Appleyarda (1994), ki jih izpostavi tudi slovenska didaktika književnosti (prim. Krakar Vogel 2004: 27; Žbogar 2010: 427; Blažić 2014: 22-24). Appleyard (1994) navaja, da najstniki najprej prestopijo mejo med t. i. bralcem - junakom ter bralcem - mislecem oziroma razmišljujočim bralcem, ki ga zanimajo literarna besedila, $v$ katerih dobro in zlo nista več strogo ločena, srečni konci niso več nujni (prim. Krakar Vogel 2004: 27; Žbogar 2010: 427). O tej razvojni stopnji Milena Mileva Blažić (2014: 23) zapiše, da mladi bralec išče zgodbe, pa tudi smisel življenja, poleg identifikacije z liki je sposoben distance. Mlade pritegnejo literarna dela, ki prikazujejo spolnost, smrt, greh, predsodke, poveča se njihovo zanimanje za medsebojne odnose, poglabljajo se v nove izkušnje, razumeti želijo svojo okolico in vrednote drugih (Žbogar 2010: 427). V srednješolskem obdobju se razvija razmišljujoči bralec, ${ }^{4}$ ki reflektira moralna, socialna in psihološka vprašanja (Žbogar 2010), zaznava vsebino in obliko, presoja literarnost, pri njegovem branju pa sta v ospredju večpomenskost in kritičnost (Blažić 2014: 23). Naslednja razvojna faza literarne zmožnosti v obdobju sekundarnega izobraževanja je t. i. bralec interpret. Kot navaja Boža Krakar Vogel (2004: 27), ga določa zanimanje za "globlji in kompleksnejši prodor v literarnost literarnega besedila."

Dramsko besedilo Simone Semenič Pepelka ${ }^{5}$ je primerno za osnovnošolsko stopnjo literarnega branja do razvoja bralca - misleca, saj spodbuja razmislek o medsebojnih odnosih, pričakovanjih, ki jih ima družba do žensk, z ironijo pa bralcu omogoča distanco do likov. Prikazuje lastnosti, ki jih okolje pripisuje ženski, tj. lepota, milina, ustrežljivost in zadržanost (Semenič 2014). Pepelka se $v$ dramskem besedilu prelevi iz žrtve $v$ emancipirano in samozavestno žensko, in sicer najprej s tem, ko se upira manipulacijam mačehe in polsester ter si obleko za ples zašije sama, na koncu pa s tem, da namesto neodgovornega princa, ki na žensko gleda kot na objekt, raje izbere preprostega kuharja, s katerim je zgradila prijateljski odnos.

Delo Varje Hrvatin Kako sem postal lisičje krzno ${ }^{6}(2014)$ je primerno za srednješolsko obdobje oziroma razmišljujočega bralca in bralca interpreta, saj spodbuja kritičnost in raziskovanje forme ter večpomenskosti. Učencem ga lahko predstavimo kot primer dramatike, ki ni neposredno uprizorljiva, saj prikazuje svobodne domišljijske predstave, ki se rojevajo po načelu prostih asociacij, in preskoke časa ter prostora. Zaradi samonanašalnosti - liki npr. razpravljajo o postopkih dram-

4 Po Appleyardovi sistematizaciji sledi še stopnja, značilna za odraslega bralca, tj. pragmatičnega bralca, ki ga zanimajo "različna branja, eskapizem, iskanje resnice in predvsem zelo uporabno in informativno znanje (Blažić 2014: 24).

5 Delo je leta 2014 uprizorilo Lutkovno gledališče Ljubljansko v režiji Ivane Diljas, nastalo je s sodelovanjem Branka Završana.

6 Besedilo je bilo leta 2018 bralno uprizorjeno v Mini teatru v režiji Nine Ramšak. 
skega besedila, v katerem nastopajo - je tudi priložnost, da mladi bralci utrjujejo znanje o dramski strukturi. Drama, ki se dogaja v krzneni deželi, kjer je na oblasti zlobna kraljica, pa tematizira tudi družbene prisile.

\section{Vira}

Semenič, Simona, 2014: Pepelka. Tipkopis.

Hrvatin, Varja, 2018: Kako sem postal lisičje krzno. Tipkopis.

\section{Literatura}

APPLEYARD, Joseph A., 1994: Becoming a Reader: The Experience of Fiction from Childhood to Adulthood. Cambridge: Cambridge University Press.

BLAŽıĆ, Milena Mileva, 2014: Branja mladinske književnosti. Ljubljana: Pedagoška fakulteta.

KRAKAR VOGEL, Boža, 2004: Poglavja iz didaktike književnosti. Ljubljana: DZS.

PEZDIRC BARTOL, Mateja, 2009: Raznovrstnost poetik slovenskih dramatičark v zadnjem desetletju. Miran Hladnik (ur.): Četrto slovensko-hrvaško slavistično srečanje. Ljubljana: Filozofska fakulteta. 193-201.

ŽBOGAR, Alenka, 2010: Ljubezen v sodobni slovenski kratki pripovedni prozi in srednješolski pouk književnosti. Alojzija Zupan Sosič (ur.): Sodobna slovenska književnost (1980-2010). Obdobja 29. Ljubljana: Znanstvena založba Filozofske fakultete. 425-431. 